\title{
Entrepreneurial and Market Orientation as Determinants of Postharvest Factors for Muntok Pepper by Farmers
}

\author{
Evahelda * (D), Iwan Setiawan (D), Rati Purwasih (D), and Rufti Puji Astuti \\ Department of Agribusiness, Faculty of Agriculture, Fisheries, and Biology, \\ Universitas Bangka Belitung, 33172, Bangka, Bangka Belitung Islands Province, Indonesia \\ *Corresponding Author: evaheldaubb@gmail.com
}

\begin{abstract}
ARTICLE INFO
Publication Info:

Research Article

How to cite:

Evahelda, E., Setiawan, I.,

Purwasih, R., E Astuti, R. P.

(2021). Entrepreneurial and

Market Orientation as

Determinants of Postharvest

Factors for Muntok Pepper by

Farmers. Society, 9(1), 160-173.

DOI: 10.33019/society.v9i1.256

Copyright (C) 2021. Owned by Author(s), published by Society

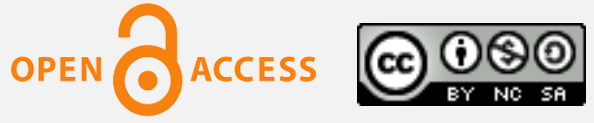

This is an open-access article.

License: Attribution-

NonCommercial-ShareAlike (CC BY-NC-SA)

\section{ABSTRACT}

The problem of Muntok Pepper business performance continues to decline due to the inability of farmers to face price uncertainty, recognize and understand market conditions. The fact is that the number of business actors continues to grow. Competing to face changes in the business environment is necessary, so entrepreneurial farmers are needed. This study aims to look at the postharvest process carried out by Muntok Pepper farmers and analyze whether entrepreneurial orientation and market orientation are determinant factors that affect the postharvest handling process. The research method used a survey method involving 60 farmers. Using Structural Equation Modeling (SEM), data analysis was carried out using smart Partial Least Squares (PLS). The results showed that the postharvest handling process was significantly influenced by entrepreneurial orientation and market orientation, but entrepreneurial orientation influence was greater than market orientation. Farmers carry out postharvest handling of Muntok Pepper in two stages. 50\% of farmers carry out threshing, soaking, and drying processes. $50 \%$ of farmers do not do the sorting, grading, and milling process. Farmers' decisions in postharvest handling are more influenced by the influence of the entrepreneurial orientation of farmers. Farmers who are motivated to excel, dare to take risks, and are willing to innovate by using new production methods tend to carry out a good postharvest handling process, not only threshing, soaking, and drying but also sort and process pepper derivative products.
\end{abstract}

Received: November 6, 2020;

Accepted: January 11, 2021;

Published: June 30, 2021;

\section{Keywords: Entrepreneurial Orientation; Market Orientation; Muntok Pepper; Postharvest}

Copyright (C 2021. Owned by Author(s), published by Society. This is an open-access article under the CC-BY-NC-SA license. 


\section{Introduction}

Pepper is one of Indonesia's export commodities. Pepper is also a prima donna commodity in plantation commodities. Indonesia's contribution as a pepper-producing country once ranked first globally, but in 2017 Indonesia only contributed 19\%, far below Vietnam's 27\% contribution (Sulaiman \& Darwis, 2019). The problem of decreasing contribution cannot be separated from the problem of decreasing pepper production. Vietnam's pepper production until 2019 continued to increase far above the value of Indonesian pepper production (Figure 1).

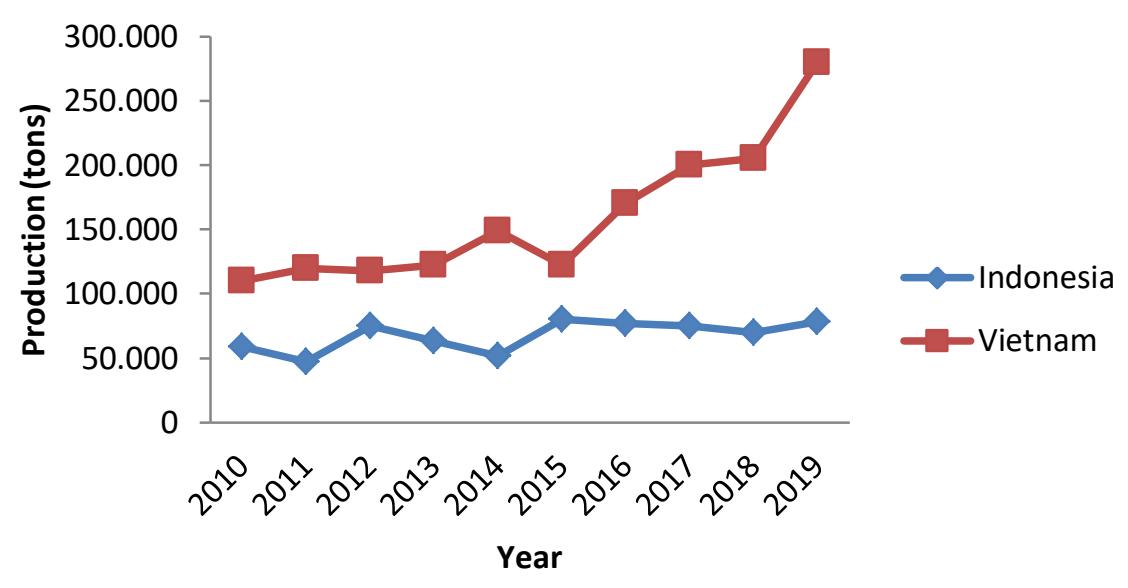

Figure 1. Indonesia's and Vietnam's pepper production Source: IPC (2020)

Bangka Belitung Islands Province is one of the central regions for producing Muntok Pepper commodities and providing export supplies in Indonesia. Pepper cultivated in almost all districts is unique. Pepper farming in the Bangka Belitung Islands Province is entirely controlled by the community (Heryanto \& Nugraha 2018). Pepper farmers are one of the community's main livelihood choices. Still, the current phenomenon is a shift in livelihood choices from pepper farmers to oil palm farmers, rubber, or even back to being tin miners. The reason is that the pepper business performance is currently declining and has no real impact on the welfare of farmers.

One of the problems in the performance of the Muntok Pepper business, which has decreased, is the inability of farmers to determine prices in marketing their products. This condition shows that farmers have not been able to compete in the face of a rapidly changing business climate. The inability of farmers to compete in the market can be caused by problems in the ability of farmers to recognize and understand market conditions and the ability and courage to take opportunities that have not received attention. This is because only entrepreneurial farmers can compete and face the changing business environment. This means that to overcome the problem of farmers' inability to compete is to forge entrepreneurial farmers, who are market-oriented, dare to take risks, continue innovating, and pay attention to postharvest activities to provide consumer satisfaction.

A comprehensive study of the marketing performance of Muntok Pepper, both in terms of products and human resources, is still needed to know the level of success of business actors in dealing with and responding to a dynamic business environment. Marketing performance is influenced by many internal and external factors, including creating competitive advantage, postharvest handling, market orientation, and entrepreneurial orientation (Witjaksono, 2014; Zebua \& Priyanto, 2017). Marketing performance is assessed based on the status of farmer

Copyright ( $(2021$. Owned by Author(s), published by Society. This is an open-access article under the CC-BY-NC-SA license. https://doi.org/10.33019/society.v9i1.256

161 
orientation towards the market and entrepreneurship. It is hoped that the results obtained will not only provide information on whether the Muntok Pepper farmers are entrepreneurial but also provide an overview of the condition of market orientation at the farmer level, how the market orientation is formed, and whether these conditions influence postharvest handling activities carried out by farmers. Market orientation also plays a role in influencing the form of postharvest handling. According to Kristono \& Nadapdap (2019) and Zebua \& Priyanto (2017), the postharvest handling process of chrysanthemums by farmers in the Bandungan Sub-district is influenced by market orientation.

This study suspects that farmers' inability to compete is due to product quality problems and the absence of efforts to create a competitive advantage. Postharvest handling at the farmer level varies and is thought to be influenced by the attitude of farmers who are not marketoriented and entrepreneurial orientation. Therefore, it is important to examine whether market orientation and entrepreneurial orientation influence the postharvest handling process by Muntok Pepper farmers.

\section{Literature Review}

Entrepreneurial orientation is the orientation of companies with principles on efforts to identify and exploit opportunities (Lee \& Chu, 2011). Entrepreneurship orientation is also defined as an effort to take innovative, proactive, autonomous, and aggressive risks as a strategy to beat competitors. Entrepreneurial orientation can be seen from autonomy, innovation, risk-taking, pro-activity, and competitive aggressiveness can vary independently, depending on the environmental and organizational context (Lumpkin et al., 2010). In addition, the actions of business actors to seek new opportunities innovatively, dare to take risks, and proactively have a close relationship with the concept of Entrepreneurship Orientation. Ahimbisibwe \& Abaho (2013) state that companies with a strong entrepreneurial orientation will be more daring to take risks and not just stick to past strategies. In addition to the ability to take risks, the main dimension of entrepreneurial orientation is innovation, namely the willingness and ability of companies to participate and support new ideas and creative processes, which result in new technological processes, services, and products (Witjaksono, 2014). According to Witjaksono (2014), entrepreneurship orientation consists of innovation, proactivity, and risk-taking indicators. Kumalaningrum (2012) states that entrepreneurshiporiented companies can better achieve their target market and market position than competitors. Entrepreneurship-oriented companies are constantly observing market changes and responding quickly to changes. The entrepreneurial orientation of the company creates the company's ability to be proactive and more willing to take risks so that it has more ability to innovate than competitors and has a competitive advantage through the value of customer satisfaction created.

The postharvest handling process has a role in determining product quality. The forms of postharvest handling carried out by farmers include the sorting, grading, and packaging processes (Zebua \& Priyanto 2017; Kristono \& Nadapdap, 2019). The structure of postharvest handling based on a market-oriented culture ultimately impacts the sustainability of product purchases by customers (Zebua \& Priyanto, 2017). Many factors influence the postharvest handling process. According to Kristono \& Nadapdap (2019) and Zebua \& Priyanto (2017), the postharvest handling process of chrysanthemums by farmers in the Bandungan Sub-district is influenced by market orientation, mainly due to customer-oriented capabilities.

Market orientation has a positive influence on competitive advantage and marketing performance. Dewi \& Ekawati (2017) show that the effect of market orientation on marketing

Copyright ( $(2021$. Owned by Author(s), published by Society. This is an open-access article under the CC-BY-NC-SA license. https://doi.org/10.33019/society.v9i1.256

162 
performance is obtained through the competitive advantage variable, which can mediate the effect of market orientation on marketing performance. Market orientation has a positive influence on the postharvest handling process of chrysanthemums. The causal relationship between variables of entrepreneurial orientation, market orientation, and postharvest handling processes in this study is analyzed by looking at how market orientation affects the postharvest handling process directly and how direct entrepreneurial orientation influences the postharvest process. This study also tries to analyze whether there is an influence of market orientation on the postharvest process through entrepreneurial orientation.

\section{Research Methodology}

This study was conducted in South Bangka Regency, Bangka Regency, and Central Bangka Regency. The study was conducted from April 2020 to September 2020. The types of data used in this study were primary and secondary data. Primary data were obtained from information sources through observation, interviews, and discussions guided by the questionnaire. Secondary data were obtained from related institutions and literature studies. The research method used is the survey method, involving 60 farmers as respondents. The researcher used a simple random sampling method in determining the research sample. The data that has been obtained is then processed and analyzed descriptively, both qualitative and quantitative. Quantitative data were processed with the help of the Microsoft Excel 2010 program and analyzed by Structural Equation Modeling (SEM) analysis using smart Partial Least Squares (PLS). The data analysis process is carried out through 2 stages: the analysis of the model or the analysis of the Outter Model (measurement model) and the analysis of the Inner Model (structural model). Evaluation of the measurement model is done by looking at the Loading Factor $(\lambda)$ value. It is valid if it has a Loading Factor $(\lambda)$ value greater than 0.5 . The significance test in evaluating the structural model is based on the estimated path parameter coefficient value, and the $\mathrm{t}$-value is more than 1.96. The significance test of the estimated path parameter coefficients was carried out using the resampling method, namely bootstrapping. The research variables observed in detail can be seen in (Table 1).

\section{Table 1. Research Variables}

\begin{tabular}{|c|c|c|}
\hline No & Latent Variables & Manifest Variables \\
\hline 1 & $\begin{array}{l}\text { Entrepreneurial } \\
(\mathrm{X} 1)\end{array}$ & $\begin{array}{l}\text { Willingness/ability of farmers to create/use new } \\
\text { ideas, products, or methods (X1.1); } \\
\text { - Courage/ability of farmers to face risks in running a } \\
\text { business with careful calculations and have an } \\
\text { anticipation of completion (X1.2); } \\
\text { - Encouragement/desire of pepper farmers to achieve } \\
\text { success (X1.3); }\end{array}$ \\
\hline 2 & Market Orientation (X2) & $\begin{array}{l}\text { Efforts made by farmers to understand customer } \\
\text { needs and wants (X2.1); } \\
\text { - Farmers' efforts to understand the strengths and } \\
\text { weaknesses of their products and strategies from } \\
\text { competitors (X2.2); } \\
\text { - Farmers' efforts to seek information about market } \\
\text { conditions }(X 2.3)\end{array}$ \\
\hline
\end{tabular}

Copyright $\odot$ 2021. Owned by Author(s), published by Society. This is an open-access article under the CC-BY-NC-SA license. https://doi.org/10.33019/society.v9i1.256

163 
Entrepreneurial and Market Orientation as Determinants of Postharvest Factors for Muntok Pepper by Farmers

\begin{tabular}{|c|c|c|}
\hline No & Latent Variables & Manifest Variables \\
\hline 3 & Postharvest Process (Y) & $\begin{array}{l}\text { - Sorting products that are feasible and not feasible } \\
\text { (pepper groats, ash pepper, light pepper (Y1.1); } \\
\text { - Product grouping based on quality (Y1.2); } \\
\text { - Farmers' treatment in pepper packaging based on the } \\
\text { suitability of the size and type of packaging container } \\
\text { (Y1.3); } \\
\text { - Provide product information on the packaging(Y1.4); } \\
\text { - The technology and methods of farmers in the } \\
\text { process of removing the skin from pepper fruit } \\
\text { through soaking and its impact on pepper quality } \\
\text { (Y.5); } \\
\text { - The technology used and the method of farmers in } \\
\text { the threshing process and their impact on pepper } \\
\text { quality(Y1.6); } \\
\text { - The technology used and the farmer's method of } \\
\text { drying, and its impact on pepper quality (Y1.7) }\end{array}$ \\
\hline
\end{tabular}

The research model was built with two exogenous latent variables, namely, (X1) entrepreneurial orientation and (X2) market orientation, one exogenous latent variable (Y1) postharvest process. The research model that was built also involved thirteen manifest variables (Table 1).

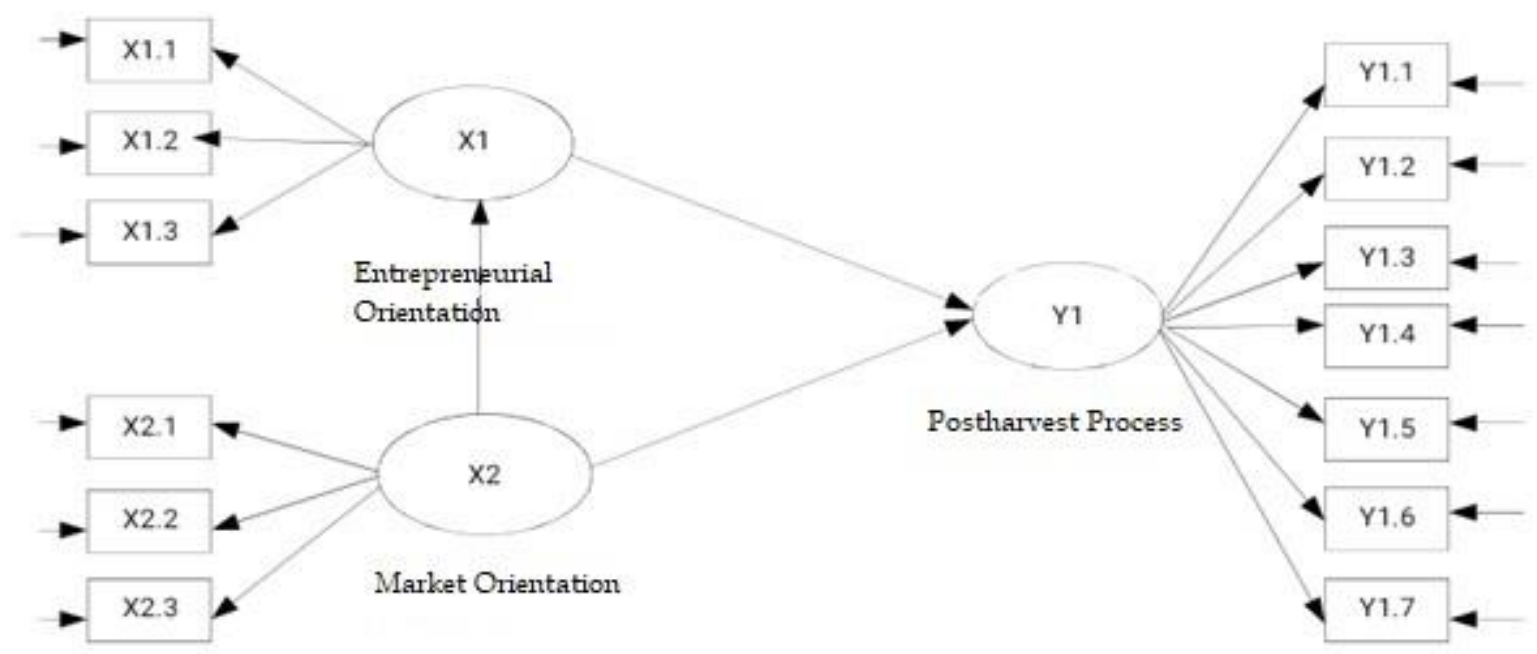

Figure 2. Cross-Model Diagram Research on entrepreneurial orientation and market orientation as determinants of factors affecting the postharvest process by Muntok Pepper farmers

\section{Results and Discussion}

The postharvest handling process has a role in determining product quality. This study involved farmers who are members of farmer groups in the Bangka Regency and South Bangka Regency. The postharvest handling process, entrepreneurship orientation, and market orientation were measured based on assessing farmers' perceptions. The detailed measurement results are in Table 2. Based on the data in Table 2, it can be seen that the percentage of farmers' perceptions of the three variables as a whole is in the high category. Forty-nine 
farmers, or $81.675 \%$, assessed the high category, and ten farmers, or $16.67 \%$, gave a very high rating. This means that farmers' assessments of indicators of entrepreneurial orientation, market orientation, and postharvest handling processes are dominated by statements of agreeing to agree strongly.

Table 2. Percentage of farmers' perceptions of entrepreneurial orientation, market orientation, and postharvest handling based on the perception rating category scale

\begin{tabular}{|l|r|r|}
\hline Perception Category & $\begin{array}{r}\text { Number of Respondents } \\
\text { (People) }\end{array}$ & Percentage (\%) \\
\hline Very high & 10 & 16.67 \\
\hline High & 49 & 81.67 \\
\hline Low & 1 & 1.67 \\
\hline Very low & 0 & 0 \\
\hline Total & $\mathbf{6 0}$ & $\mathbf{1 0 0}$ \\
\hline
\end{tabular}

\subsection{Muntok Pepper Postharvest Process}

The postharvest handling process for Muntok Pepper, by farmers, is carried out in two stages; namely, the first stage consists of fruit threshing, soaking, grinding, and drying, while the second stage consists of sorting, grading, labeling, and packaging processes. The postharvest handling process is assessed based on the perspective or perception of the farmer. The detailed measurement results are in Figure 3. This study found that pepper farmers carried out all postharvest processes, namely threshing, soaking, milling, drying, sorting, grading, labeling and packaging. Based on the data in Figure 3, it can be seen that in the first stage, most farmers or more than $50 \%$ of farmers carried out the soaking and drying process.

In contrast, the threshing and milling process was only carried out by some farmers who were domiciled in Bangka Regency. Based on the data in Figure 3, it can also be seen that in this second stage, more than $50 \%$ or the majority of farmers did not carry out the grading, labeling, and packaging processes. In contrast, some farmers still carried out the sorting process. The sorting, grading, labeling, and packaging process is mainly done by farmers who live in South Bangka Regency. According to Arwati (2018), farmers in Tellu Boccoe Village can produce highquality white pepper because they have knowledge and skills in postharvest processing activities.

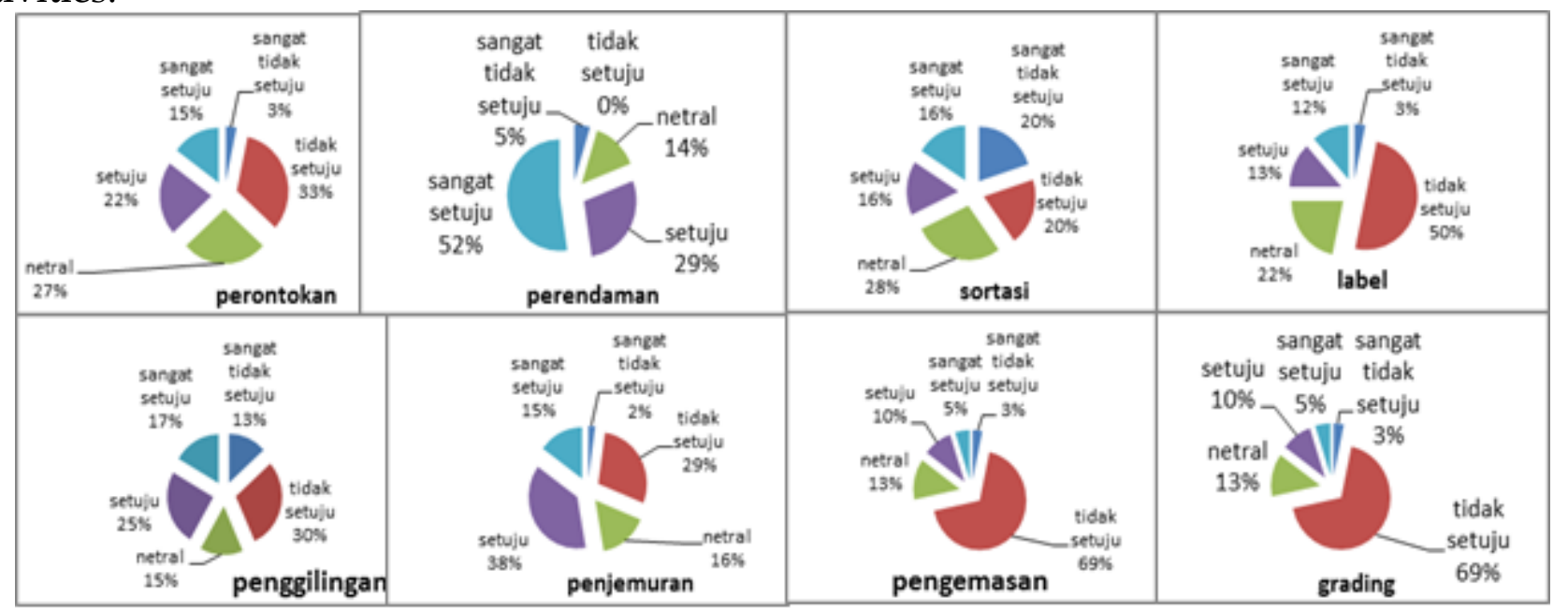

Figure 3. Pepper postharvest handling process

Copyright ( $(2021$. Owned by Author(s), published by Society. This is an open-access article under the CC-BY-NC-SA license. https://doi.org/10.33019/society.v9i1.256 


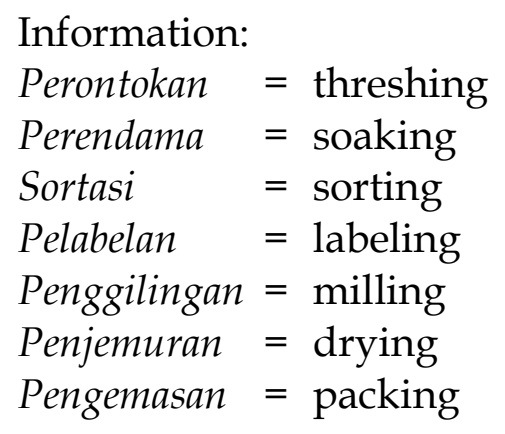

Likert scale:

Sangat Tidak Setuju $=$ Strongly Disagree

Tidak Setuju $\quad=$ Disagree

Netral $\quad$ Neutral

Setuju $\quad=$ Agree

Sangat Setuju = Strongly Agree

\subsection{Entrepreneurial Orientation}

The entrepreneurial orientation in this study is observed from three indicators, namely farmer innovation, willingness to take risks and achievement motivation. Kumalaningrum (2012) stated that companies that are entrepreneurship-oriented, have more ability to innovate, are more proactive in understanding market conditions, and dare to take risks. Entrepreneurialoriented farmers in managing their farms are thought to have the ability to innovate and take better risks, as well as to be more proactive. Entrepreneurial orientation is assessed based on the perspective and perception of farmers, the detailed measurement results are shown in Figure 4.

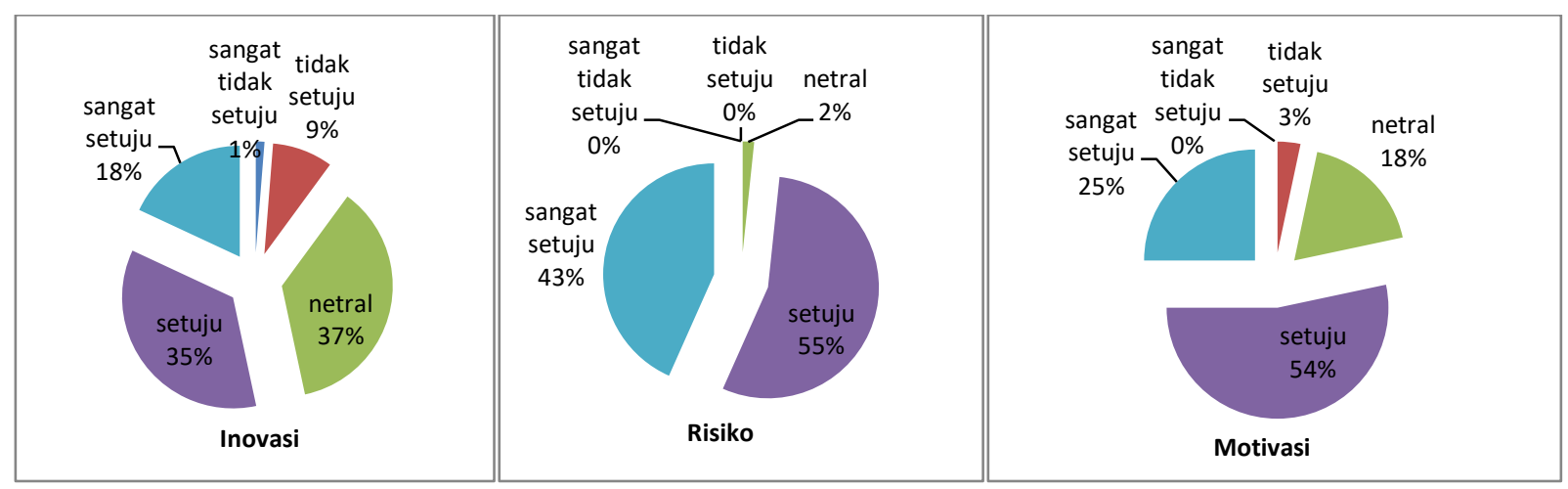

Figure 4. Innovation, Risk, and Motivation

Information:

Inovasi $\quad=$ innovation

Risiko $\quad=$ risk

Motivasi $=$ motivation

Innovation in this study is assessed based on the attitude of farmers to their willingness to innovate, the level of technology use, and the use of new methods in production, postharvest processing, and marketing. Muntok Pepper farmers are entrepreneurship-oriented in managing their farms. More than $50 \%$ of farmers agree that farmers currently can innovate. The results of 
the assessment of farmers' perceptions in Figure 4 provide information that as many as $35 \%$ of farmers agree and 18\% strongly agree that farmers can innovate. The willingness to innovate determines the ability of farmers to innovate products. The results of previous research by Parkman et al. (2012), Hafeez et al. (2012), Wang et al. (2015), and Suyanto \& Pratono (2014) found a positive and significant relationship between the ability to innovate and the ability to be entrepreneurship-oriented. In this case, the entrepreneurial orientation variable is indicated by indicators of flexibility, anticipation, proactiveness, innovation, and the courage to take risks. The higher the entrepreneurial orientation ability, the higher the ability to innovate. The data in Figure 4 also provides information that not all farmers have the ability to innovate. $37 \%$ of farmers gave a neutral statement which means that there are still farmers who do not know the development of innovation in managing to farm, and still use the same method of production, postharvest processing, and marketing the results, from the beginning of the business until the time of the research.

The risks, in this study, is assessed based on farmers' knowledge about the risks types, courage to take risks, and ability to respond the risks impact. Muntok Pepper farmers are entrepreneurially oriented in managing their farms. $98 \%$ of farmers agree that they dare to take risks, respond to risks, and know risks in their work, finances, production, and investment. The assessment of farmers' perceptions in Figure 4 provides information that as many as $55 \%$ of farmers agreed, $43 \%$ stated strongly agree on the assessment of risk variables. This means that the management of Muntok Pepper farming still requires government attention because this business still contains high risks, especially in terms of production and finance.

Motivation in this study is placed as an indicator to assess the entrepreneurial orientation of farmers. Motivation is measured based on the desire of farmers to excel, the desire to maintain as a source of income, and the desire of farmers to continue to learn and understand the products that consumers want. According to Bertnus (2009), as cited in Arwati (2018), this motivation is one factor that affects a person's skills in taking action. Muntok Pepper farmers are entrepreneurially oriented in managing their farms, and farmers have high motivation. As many as $79 \%$ of farmers agreed that although there is a high risk in farming, farmers have a strong urge to continue maintaining business sustainability, obtaining maximum profits, and studying the market, and producing products that consumers want.

\subsection{Market Orientation}

Market orientation in this study is observed from three indicators, namely customer orientation, competitor orientation, and market information. Changes in consumer preferences and increasing global competition are two problems that cannot be avoided. Market-oriented farmers are needed to deal with them. Market orientation is assessed based on farmers' perspectives and perceptions, and the detailed measurement results are in Figure 5. 


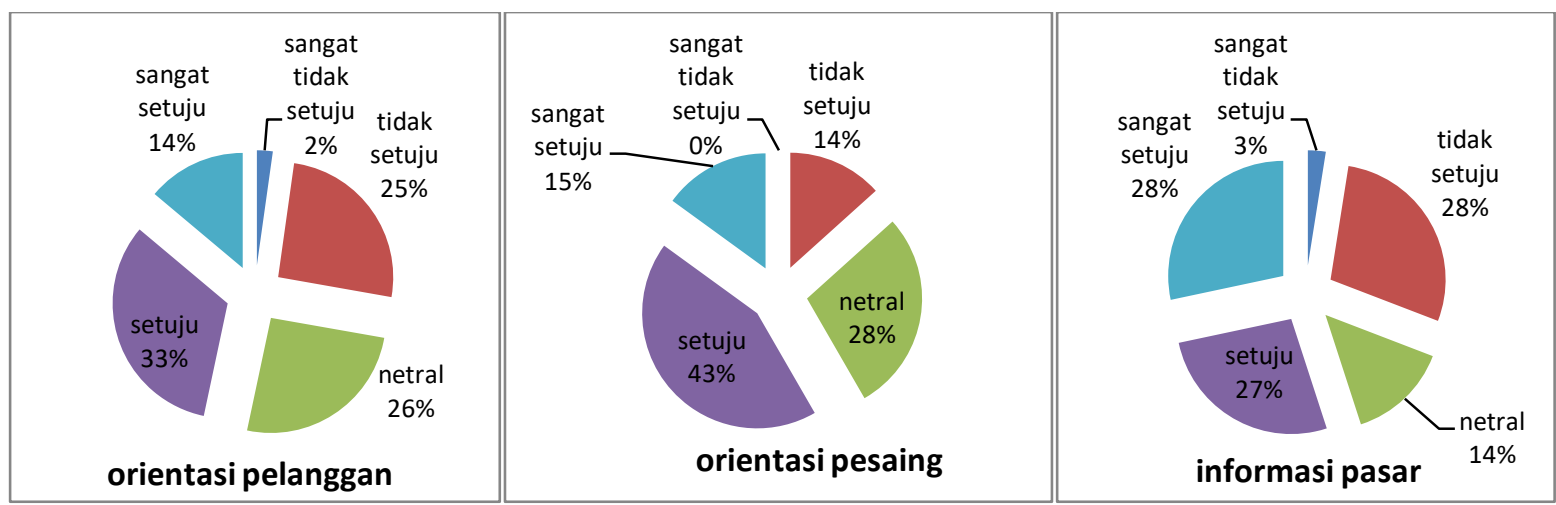

Figure 5. Customer orientation, competitor orientation, and market information

Information:

Orientasi pelanggan $=$ customer orientation

Orientasi pesaing $\quad=$ competitor orientation

Informasi pasar = market information

The data in Figure 5 means that Muntok Pepper farmers are market-oriented in managing their farming. More than $50 \%$ of farmers agree that they have been trying to be competitororiented and continue to explore market information. Based on the data in Figure 5, it can also be seen that only $47 \%$ of farmers agreed to strongly agree that they are also customer-oriented in managing their farms. This means that in managing their farming, Muntok Pepper farmers are already market-oriented by actively seeking market information related to price developments, knowing who their competitors are, knowing competitors' weaknesses and strengths of products, postharvest technology, and competitors' marketing strategies. However, not all farmers are customer-oriented. $27 \%$ of farmers stated that they do not know the target market and product quality needed by customers. In comparison, $26 \%$ of farmers have tried to find out the target market and product quality needed by customers but cannot produce according to customer needs.

\subsection{Determinant Analysis of Factors Affecting Muntok Pepper Farmers Carrying Out the Postharvest Process}

\subsubsection{Measurement Model Evaluation}

The main purpose of evaluating the measurement model is to determine whether an indicator (manifest variable) can measure the construct (latent variable). The results of the analysis of the measurement model (Outer Model) through the PLS algorithm process, three indicator variables in the latent postharvest process are not valid. After verifying the model, all indicator variables are valid with the acquisition loading factor value greater than 0.5 . This means that the overall indicators used can measure the construct. The overall indicators of the measured variables are valid, reflecting the variables of market orientation and postharvest entrepreneurship orientation. The value of the loading factor in Table 3 shows that the latent entrepreneurial orientation and dominant market orientation are strongly reflected by the innovation indicator (X1.1) and market information (X2.3). In contrast, there is an immersion indicator (Y1.5) in the latent postharvest process that most dominant strongly reflects latent. 
Entrepreneurial and Market Orientation as Determinants of Postharvest Factors for Muntok Pepper by Farmers

Table 3. The contribution of the personal characteristic indicator variable is based on the loading factor value and $t$-value, as well as the reliability of the observation variable

\begin{tabular}{|c|c|c|c|c|c|c|c|}
\hline $\begin{array}{c}\text { Latent } \\
\text { Variables }\end{array}$ & Manifest Variables & $\begin{array}{c}\text { Loading } \\
\text { Factor }\end{array}$ & $\begin{array}{c}\text { T- } \\
\text { value }\end{array}$ & $\begin{array}{c}\text { Cronbach's } \\
\text { Alpha }\end{array}$ & AVE & Validity & Reliability \\
\hline \multicolumn{8}{|c|}{ Entrepreneurial Orientation $(\mathrm{X} 1)$} \\
\hline & Innovation & $\begin{array}{l}0.886 \\
0.755\end{array}$ & & 0.830 & 0.533 & Valid & Reliable \\
\hline \multicolumn{8}{|c|}{ Market Orientation $(\mathrm{X} 2)$} \\
\hline & $\begin{array}{l}\text { Customer Orientation } \\
\text { Competitor Orientation } \\
\text { Market Information }\end{array}$ & $\begin{array}{l}0.724 \\
0.536 \\
0.775\end{array}$ & & 0.882 & 0.741 & $\begin{array}{l}\text { Valid } \\
\text { Valid } \\
\text { Valid }\end{array}$ & Reliable \\
\hline \multicolumn{8}{|c|}{ Postharvest Process $(\mathrm{Y})$} \\
\hline & $\begin{array}{l}\text { Sorting } \\
\text { Grading } \\
\text { Packing } \\
\text { Labelling } \\
\text { Soaking } \\
\text { Threshing } \\
\text { Drying } \\
\text { Milling } \\
\end{array}$ & $\begin{array}{c}-0,446 \\
0,364 \\
0,784 \\
0,614 \\
0,804 \\
-0,432 \\
0,621 \\
-0,446 \\
\end{array}$ & & 0,780 & 0,560 & $\begin{array}{c}\text { Invalid } \\
\text { Invalid } \\
\text { Valid } \\
\text { Valid } \\
\text { Valid } \\
\text { Invalid } \\
\text { Valid } \\
\text { Invalid } \\
\end{array}$ & Reliable \\
\hline
\end{tabular}

Evaluation of the measurement model is also carried out by assessing reliability based on the AVE value and Composite Reliability (CR). The results of data analysis on the measurement model also provide information that the indicator variables used to meet the reliable requirements. Cronbach's Alpha values showed that numbers greater than 0.7 and the Average Extracted Variance (AVE) were greater than 0.5 (Error! Reference source not found.). This means that all the indicator variables used can measure the construct reliably.

\subsubsection{Structural Model Evaluation}

The purpose of evaluating the structural model is to see the relationship between latent constructs by looking at the results of the estimated path parameter coefficients and their level of significance (Ghozali \& Latan, 2012). The evaluation of the structural model in this study was conducted to see three forms of latent construct relationships, namely, the influence of entrepreneurial orientation on the postharvest process (H1), the effect of market orientation on the postharvest process (H2), and the effect of market orientation on the postharvest process, through entrepreneurial orientation (H3). The results of the significance test of all hypotheses built in this study can be seen in Table 4.

Table 4. The coefficient value of the path parameter of the influence of entrepreneurial orientation and market orientation on farmers carrying out the postharvest process

\begin{tabular}{|lrrr|}
\hline \multicolumn{1}{|c}{ Hypothesis } & $\begin{array}{r}\text { Original } \\
\text { Sample }\end{array}$ & T-value & Description \\
\hline Entrepreneurial orientatiom $>$ postharvest & 0.460 & $3.144^{*}$ & Significant \\
\hline Market orientation $>$ postharvest & 0.320 & $2.016^{*}$ & Significant \\
\hline $\begin{array}{l}\text { Market orientation }>\text { entrepreneurial orientation }> \\
\text { postharvest }\end{array}$ & 0.267 & $2.823^{*}$ & Significant \\
\hline
\end{tabular}

*Significance of $\mathrm{t}((0.05): 1.96)$

Copyright ( $(2021$. Owned by Author(s), published by Society. This is an open-access article under the CC-BY-NC-SA license. https://doi.org/10.33019/society.v9i1.256 
The structural model evaluation analysis results in Table 4 show that the T-value of the three causal relationships built on the research model is greater than the standard, which is 1.96. This means that market orientation and entrepreneurial orientation are determinant factors for farmers to carry out postharvest handling processes. Entrepreneurial orientation and market orientation have a significant influence on the postharvest handling process of Muntok Pepper. The Original Sample value in Table 4 shows the magnitude of the path parameter coefficient value and the direction of the relationship between the two variables. The larger the coefficient value, it means that the influence of the estimated variables is getting stronger. In other words, the causal relationship is the most important in the model. The coefficient value of the entrepreneurial orientation path parameter to the postharvest process is 0.460 , greater than the effect of market orientation at 0.320 . This shows that the most important causal relationship for the postharvest variable is the entrepreneurial orientation variable of Pepper Muntok farmers.

Another result of this research is that there is a positive influence from the causal relationship that is built. The data analysis results also show an indirect effect of market orientation on the postharvest process through entrepreneurial orientation with an Original Sample value of 0.267 . This means that farmers' efforts to find price information, understand competitors' strengths and weaknesses, and understand the products needed by customers will determine the way farmers are in the postharvest handling process. The stronger the achievement motivation, the courage of farmers to take risks, and willingness to innovate, the more likely farmers can produce products according to customer requirements.

The results of previous research conducted by Kristono \& Nadapdap (2019) found that market orientation is one determinant factor influencing farmers to postharvest chrysanthemums, namely through farmers' efforts to produce chrysanthemums according to customer needs. Farmers understand that the taste of chrysanthemum consumers is determined by the type of flower, color, stem, shape, and size of the flower. This is a concern for farmers to choose the type of flowers to be planted and how to handle the harvest. The majority of customers of chrysanthemum products in the Bandungan Sub-district are decorators, and the products needed are only based on the type, color, stem length, and freshness of the flowers. Farmers do not carry out the labeling process, and the packaging innovation only uses styrofoam boxes to maintain freshness during long-distance shipments.

Pepper Muntok farmers in the sub-district of Air Gegas, South Bangka Regency believe that to obtain a favorable price, apart from the need for government policies, farmers must also produce products according to customer needs. The search for market information results in farmers being aware of the price gap at the farmer level and in the international market. Farmers understand that the pepper product needed in the international market is Pepper Muntok go green, which has a moisture content of $<12 \%$, a negative content of Escherichia coli (E. coli), and guaranteed hygiene. However, to meet customers' needs, farmers are still constrained by the amount of production that has not been able to meet the delivery target of 20 tons/month. Farmers understand that the strength of their competitors in West Bangka has produced 20 tons of go green pepper per month. Delas village farmers are innovating in using seeds, applying organic fertilizer processing technology, building standards quality of soaking ponds, building UV drier houses, and building farmer partnerships to produce go green pepper that applies quality control in postharvest handling to meet the current needs of their customers. Farmers are also trying to increase the added value of their products through processing ground pepper. Farmers continue to innovate using double seal packaging to maintain product quality and have completed product attributes on the packaging. Farmers in Petaling Banjar Village have not done this. The innovation made by farmers in Petaling Banjar

Copyright ( $(2021$. Owned by Author(s), published by Society. This is an open-access article under the CC-BY-NC-SA license. https://doi.org/10.33019/society.v9i1.256 
Village is applying fruit thresher and milling machines to separate the fruit skin after going through the soaking process.

Market orientation is one indicator of farmer entrepreneurship. According to Darmadji (2012), chili and rice farmers in Sleman Regency are market-oriented by seeking to obtain favorable prices and understanding who the consumers are, applying new methods or methods of production so that they have high entrepreneurial potential. Based on this statement, it can be understood that farmers who have a market-oriented attitude can innovate, have achievement motivation, and are willing to take risks in managing their farming. Innovation and risk-taking are the strongest dimensions of entrepreneurial orientation in this study. This is following Witjaksono (2014) that innovation is the main dimension of entrepreneurial orientation. Innovation can also be seen from a person's desire to leave the old way, get involved in new ideas. Not only that, according to Pangeran (2012), innovation is also shown by developing products to gain a competitive advantage. Pangeran (2012) also stated that a person's ability and courage to take risks are shown from his desire and commitment to take risks. The motivational dimension also influences the postharvest handling process of Muntok Pepper by farmers. This is also following the research results by Kristono \& Nadapdap (2019), which found an influence of motivation on the postharvest handling process. Motivation is defined as an urge to make decisions and act postharvest to achieve goals. The reason farmers carry out postharvest processes according to customer needs is to achieve maximum profit.

\section{Conclusion}

Based on the results obtained, it can be concluded that farmers carry out postharvest handling of Muntok Pepper through two stages. 50\% of farmers carry out threshing, soaking, and drying processes. $50 \%$ do not do the sorting, grading, and milling process. Entrepreneurial orientation and market orientation are determinant factors of farmers doing postharvest processes, both of which have a positive and significant influence on the postharvest process. Farmers' decisions in postharvest handling are more influenced by the influence of the entrepreneurial orientation of farmers.

\section{Acknowledgment}

The authors are grateful to express gratitude to Universitas Bangka Belitung for the grant funding for Lecturer Research at the Department Level in 2020 and those who have had the pleasure to cooperate during this study.

\section{Declaration of Conflicting Interests}

The authors have declared no potential conflicts of interest concerning the study, authorship, and/or publication of this article.

\section{References}

Ahimbisibwe, G., \& Abaho, E. (2013). Export Entrepreneurial Orientation and Export Performance of SMEs in Uganda. Global Advanced Research Journal of Management and Business Studies, 2(1), 056-062. Retrieved from http:/ /garj.org/garjmbs/1/2013/2/1/export-entrepreneurial-orientation-and-exportperformance-of-smes-in-uganda 
Arwati, S. (2018). Tingkat Keterampilan Petani Terhadap Pengolahan Pasca Panen Lada Di Kecamatan Ponre Kabupaten Bone. Jurnal Ecosystem, 18(3), 1263-1270. Retrieved from https://journal.unibos.ac.id/eco/article/view/778

Darmadji, D. (2012). Analisis Kewirausahaan Petani. Agrika: Jurnal Ilmu-Ilmu Pertanian, 6(1), 48 64.

Dewi, N. M. P., \& Ekawati, N. W. (2017). Peran Keunggulan Bersaing dalam Memediasi Pengaruh Orientasi Pasar terhadap Kinerja Pemasaran. E-Jurnal Manajemen Unud, 6(9), 4947-4977.

Retrieved

from

https://ojs.unud.ac.id/index.php/Manajemen/article/view/31676

Ghozali, I., \& Latan, H. (2012). Partial Least Square: Konsep, Teknik dan Aplikasi SmartPLS 2.0 M3. Semarang, Indonesia: Badan Penerbit Universitas Diponegoro.

Hafeez, M. H., Shariff, N. M., \& Mad Lazim, H. (2012). Relationship between Entrepreneurial Orientation, Firm Resources, SME Branding and Firm's Performance: Is Innovation the Missing Link? American Journal of Industrial and Business Management, 02(04), 153-159. https://doi.org/10.4236/ajibm.2012.24020

Heryanto, M. A., \& Nugraha, A. (2018). Analisis Sistem Sosial-Ekologi Lada Putih Provinsi Kepulauan Bangka Belitung. Agricore: Jurnal Agribisnis dan Sosial Ekonomi Pertanian Unpad, 3(2). https:// doi.org/10.24198/agricore.v3i2.20882

IPC. (2020). Pepper Statistical Yearbook 2019. Jakarta, Indonesia: International Pepper Community.

Kumalaningrum, M. P. (2012). Lingkungan Bisnis, Orientasi Kewirausahaan, Orientasi Pasar, dan Kinerja Usaha Mikro, Kecil dan Menengah. Jurnal Riset Manajemen dan Bisnis, 7(1), 45. https:// doi.org/10.21460/jrmb.2012.71.83

Kristono, R. J., \& Nadapdap, H. J. (2019). Karakteristik petani dan orientasi pasar sebagai pengaruh petani krisan melakukan proses pasca panen. Agriland: Jurnal Ilmu Pertanian, 7(2), 159-167. Retrieved from https://jurnal.uisu.ac.id/index.php/agriland/article/view/2024

Lee, T. K., \& Chu, W. (2011). Entrepreneurial orientation and competitive advantage: The mediation of resource value and rareness. African Journal of Business Management, 5(33), 12797-12809. Retrieved from https://academicjournals.org/journal/AJBM/articleabstract/659E31B21514

Lumpkin, G., Brigham, K. H., \& Moss, T. W. (2010). Long-term orientation: Implications for the entrepreneurial orientation and performance of family businesses. Entrepreneurship $\mathcal{E}$ Regional Development, 22(3-4), 241-264. https:/ / doi.org/10.1080/08985621003726218

Pangeran, P. (2012). Orientasi Pasar, Orientasi Kewirausahaan dan Kinerja Keuangan Pengembangan Produk Baru Usaha Mikro Kecil dan Menengah. Jurnal Riset Manajemen Dan Bisnis, 7(1), 1. https:/ / doi.org/10.21460/jrmb.2012.71.80

Parkman, I. D., Holloway, S. S., \& Sebastiao, H. (2012). Creative industries: aligning entrepreneurial orientation and innovation capacity. Journal of Research in Marketing and Entrepreneurship, 14(1), 95-114. https://doi.org/10.1108/14715201211246823

Sulaiman, A. A., \& Darwis, V. (2019). Kinerja dan Perspektif Agribisnis Lada dalam Upaya Meningkatkan Kesejahteraan Petani / Performance and Perpective Agribusiness of Agribusiness In Efforts to Increase Farmer Welfare. Perspektif, 17(1), 52. https://doi.org/10.21082/psp.v17n1.2018.52-66

Suyanto, S., \& Pratono, A. H. (2014). The Impact of Entrepreneurship Orientation, Human Capital, and Social Capital on Innovation Success of Small Firms in East Java. Jurnal Manajemen Teknologi, 13(2), 117-125. https:/ / doi.org/10.12695/jmt.2014.13.2.1

Copyright $\odot$ 2021. Owned by Author(s), published by Society. This is an open-access article under the CC-BY-NC-SA license.

https://doi.org/10.33019/society.v9i1.256

172 
Wang, K. Y., Hermens, A., Huang, K. P., \& Chelliah, J. (2015). Entrepreneurial orientation and organizational learning on SMEs' innovation. International Journal of Organizational Innovation, 7(3), 65-75.

Witjaksono, H. P. (2014). Analisis Orientasi Kewirausahaan dan Sumber Daya Internal Perusahaan terhadap Kinerja melalui Keunggulan Bersaing. Jurnal Bisnis Strategi, 23(1), 82-110. Retrieved from https://ejournal.undip.ac.id/index.php/jbs/article/view/14373

Zebua, D. D. N., \& Priyanto, S. H. (2017). Pengaruh Orientasi Pasar Terhadap Penanganan Pasca Panen Bunga Potong Krisan Di Desa Kenteng, Kecamatan Bandungan, Kabupaten Semarang. Agric, 29(1), 31. https:// doi.org/10.24246/agric.2017.v29.i1.p31-42

\section{About the Authors}

1. Evahelda obtained her Doctoral degree in Agricultural Science from Universitas Sriwijaya, Indonesia, in 2017. The author is an Assistant Professor at the Department of Agribusiness, Faculty of Agriculture, Fisheries, and Biology, Universitas Bangka Belitung, Indonesia.

E-Mail: evaheldaubb@gmail.com

2. Iwan Setiawan obtained his Master's degree from Universitas Sriwijaya, Indonesia, in 2005. The author is an Assistant Professor at the Department of Agribusiness, Faculty of Agriculture, Fisheries, and Biology, Universitas Bangka Belitung, Indonesia.

E-Mail: binri_fam@yahoo.co.id

3. Rati Purwasih obtained her Master's degree in Agricultural Economics from IPB University, Indonesia, in 2016. The author is an Assistant Professor at the Department of Agribusiness, Faculty of Agriculture, Fisheries, and Biology, Universitas Bangka Belitung, Indonesia.

E-Mail: ratipurwasih09@gmail.com

4. Rufti Puji Astuti obtained her Master's degree in Agribusiness Science from IPB University, Indonesia, in 2016. The author is an Assistant Professor at the Department of Agribusiness, Faculty of Agriculture, Fisheries, and Biology, Universitas Bangka Belitung, Indonesia.

E-Mail: ruftipuji24@gmail.com 